Original scientific paper

UDC: 572.023:639.111.7

DOI: $\underline{10.15679 / b j w r . v 2 i 1.36}$

\title{
DISTRIBUTION OF SMALL INDIAN MONGOOSE (Herpestes auropunctatus) IN THE EASTERN HERZEGOVINA - SPREADING INSIDE BALKAN MAINLAND
}

\begin{abstract}
Ćirović D. ${ }^{1}$, Toholj $D .^{2}$
Abstract: Spreading of small Indian mongoose (Herpestes auropunctatus) along Adriatic coast is well described in recent literature. However, data about its presence and spreading in mainland of Bosnia and Herzegovina are scarce. In this paper new records about distribution of small Indian mongoose in the region of Eastern Herzegovina are presented. This region is characteristic as the species was introduced few decades ago. These records confirm extension of this species’ range towards south-east along Trebišnjica river. Excluding valley of Neretva river were species was already recorded recently small Indian mongose is present in whole area of Popovo polje. Total distribution area of the small Indian mongoose in Bosnia and Herzegovina is $262.5 \mathrm{~km} 2$. So far there are no data about its presence in western from Neretva river. Having in mind that this is an invasive species, establishment of population monitoring and assessment of the impact which small Indian mongoose has on local fauna must be set as biodiversity conservation priorities in the future.
\end{abstract}

Key words: Bosnia and Herzegovina, Eastern Herzegovina, Herpestes auropunctatus, Small Indian mongoose

\section{Introduction}

Small Indian Mongoose (Herpestes uropunctatus) is described as one of the most invasive species in the world (Lowe et al., 2000). In synergy with other factors, mongoose can be considered responsible for the extinction or population reduction of many native species (Hays \& Conant, 2007). Its native distribution is southern Asia - from Iraq and Afganistan accros India to Indochina (Long, 2003). It was introduced in the second half of the 19th century to control populations of rats in sugarcane plantations and to exterminate poisonous snakes (Nellis, 1989; Hays \& Conant, 2007) in many islands of the Caribbean Sea, Pacific and Indian Ocean. It was reintroduced in Tanzania in Africa too (Long, 2003; Watari et al., 2008). At the begining of the 20th century small Indian mongoose was intruduced in the Central and South America and some Japanese islands (Watari et al., 2008).

Small Indian mongoose was introduced in the region of Dalmatia in Croatia. Eleven animals from India were released on small island Mljet in Adriatic see in 1910. Its introduction was part of a eradication program of the dense population of the venomous Horned viper (Vipera ammodytes) in this island. Introduction was very successful and mongoose has become very abundant on Mljet island. Later, animals has been translocated to few neighbouring islands and to mainland - Pelješac Penninsula and vicinity of Mostar city in Bosnia and Herzegovina (Tvrtković \& Kryštufek, 1990; Kryštufek \& Tvrtković, 1992; Kryštufek, 1995). Except territory of Croatia were species was introducted recent distribution include neigbouring Bosnia and Herzegovima and Montenegro (Barun et al., 2008; Ćirović et al., 2010)

Establishment of stable population on Adriatic coast and deeper in the mainland was unexpected because this region is far in the north in comparison to species' most northern parts of native range which is located in northern Iraq (Nellis, 1989; Cavalini \& Serafini, 1995). In this newly established region, climates,

\footnotetext{
${ }^{1}$ PhD Duško Ćirović, Faculty of Biology, University of Belgrade, Studentski trg 16, 11000 Belgrade, Serbia Corresponding author: Aleksandra Penezić, dcirovic@bio.bg.ac.rs

${ }^{2}$ Dušan Toholj, Biological Researching Organization "Southern Blue Sky", Trebinjskih brigada 2, 89101 Trebinje, Bosnia and Herzegovina
} 
are significantly cooler, with temperatures in January lower than $10^{\circ} \mathrm{C}$ - which represent known isoterm limits of species distribution (Nellis \& McManus 1974; Ebisu \& Whittow, 1976).

Although primary motive of introduction was reduction of rats on the sugar cane plantations or biological control of poisonous snakes populations that threatened the local residents, mongooses, being generalist species, started to prey on many local native species (Pimentel, 1955; Gorman, 1975; Cavallini \& Serafini, 1995; Watari et al., 2008). In the last few decades, the small Indian mongoose has been spreading along Adriatic cost in Croatia and Monenegro and in the mainland of Bosnia and Herzegovina (Barun et al., 2008; Ćirović et al., 2010). In this paper we present new data about distribution and spreading of the small India mongoose in the mainland of Eastern Herzegovina region (Bosnia and Herzegovina). Aslo we discused potential directions of spreeding in the Bosnia and Herzegovina.

\section{Material and methods}

Since the spreading of small Indian mongoose was found along Adriatic coast in Montenegro (Ćirović et al., 2011) and the first indication of its spreading in Eastern Herzegovina (Barun et al., 2008), regular field studies were organized in order to collect information on mongoose presence in this area. Fieldwork was especially intensified since the spread of the mongoose was registered in the neighbouring Montenegro. In the order to collect data about species presence/distribution, field studies were organized since 2011. The first data were collected through questionnaires, followed by observations and recordings of the animal casualties as road-kill.

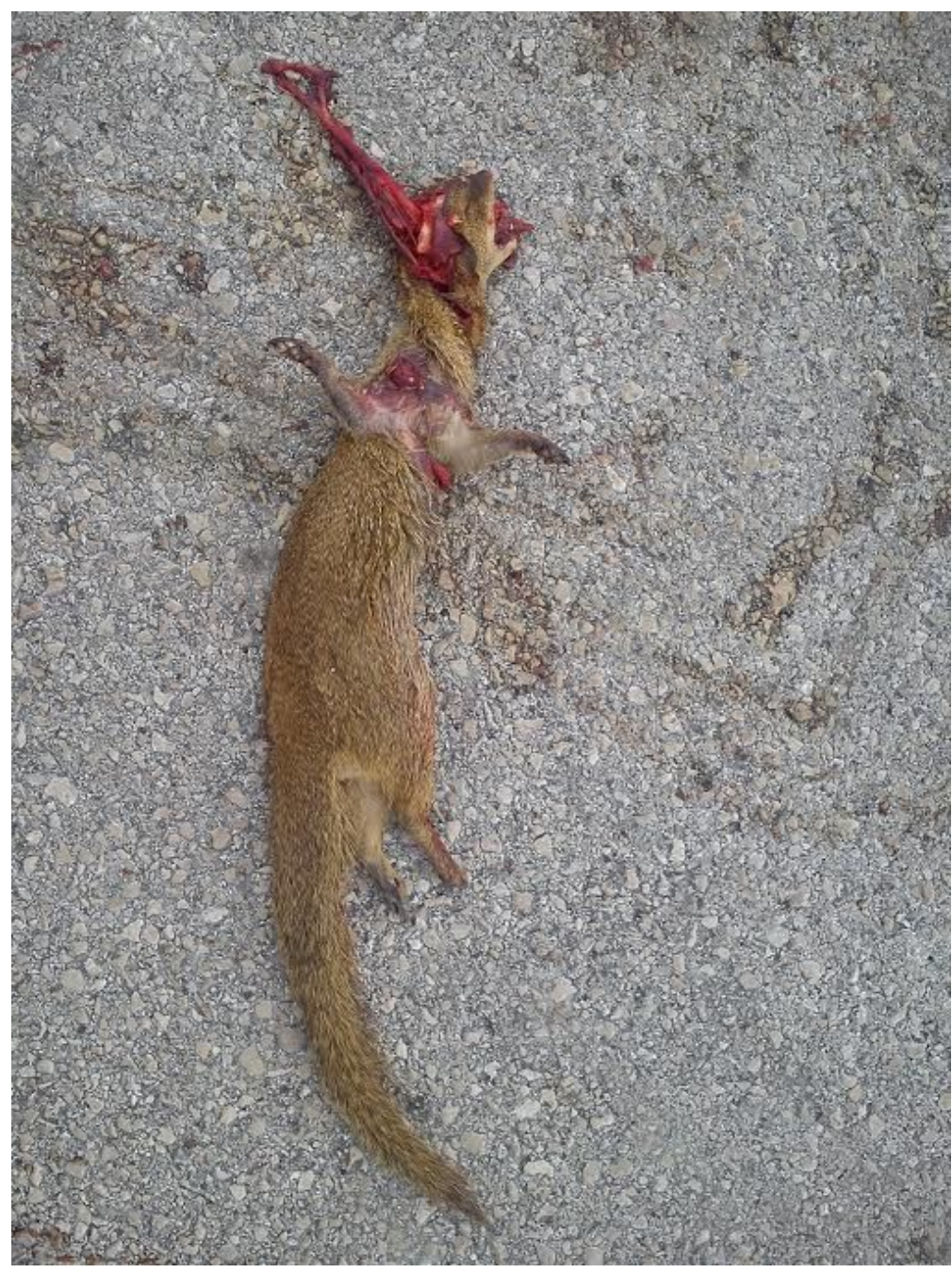

Figure 1 Mongoose was found dead on the road at suburb of Trebinje 
In order to present recent data about distribution of small Indian mongoose, beside authors' original data, all published data in available literature for this region were collected. All collected data on small Indian mongoose presence in the region of Eastern Herzegovina were obtained by field mapping using GPS. Besides the standard cartography, Manifold 5.50 software GIS tools (Manifold System, CDA International Ltd.) were used for estimation of the surface area of the present range of mongooses in this region too.

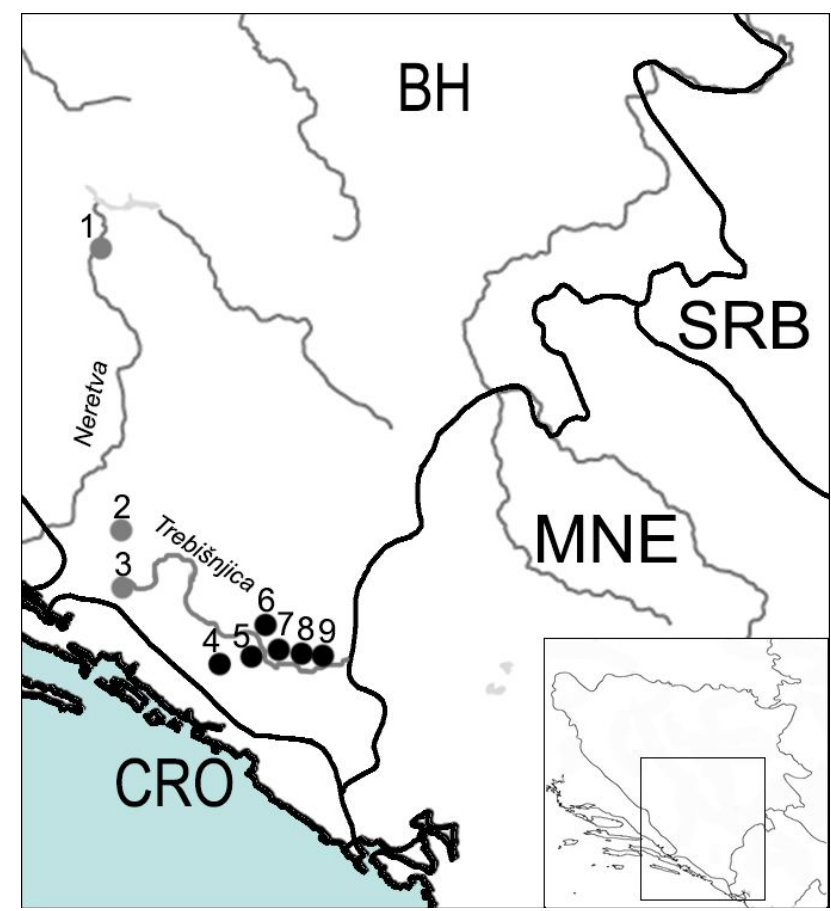

Legend: gray points literature records, bleck pints records from this study.

1 Mostar, 2 road between Stolac i Hutovo, 3 Čvaljina, 4 Hum, 5 Desin selo, 6 Staro Slano, 7 Monastry Tvrdoš, 8 Trebišnjica river, 9 Trebinje

Figure 2. Records of small Indian mongoose in region of Eastern Herzegovina

\section{Results and Discussion}

In summer of 2014, the first mongoose was registered outside the previously known range. In August one animal was found dead on the road near the village Hum and another one was observed on the road in the vicinity of the monastery Tvrdoš. In March 2015 one animal was found dead on the road at suburb of town Trebinje (Figure 1). Later during the summer mongooses were observed almost daily in this area. During July of the same year animals were observed in near villages Desin selo and Staro Slano, and in August again in the vicinity of monastery Tvrdoš. In October 2014 in dense vegetation along river Trebišnjica two kilometers downstream from the city of Trebinje, a male mongoose was caught alive in the trap. In total six new localities in the region of Eastern Herzegovina were recorded. All records indicate that present distribution includes entire area of Popovo polje and it seems that Trebišnjica River is corridor used for spreading toward south-east in this region. All of these findings are located at altitudes up to 260 meters. With these new records the area of present distribution of mongoose in Bosnia and Herzegovina is 262.5 $\mathrm{km}^{2}$.

Only three localities with small Indian mongoose were previously recorded in western Herzegovina mainland in the literature (Kryštufek \& Tvrtković, 1992; Lelo, 2007; Barun et al., 2008). So far there are no information about presence of mongooses western from Neretva River (Figure 2). According to the previously published data, distribution of the small Indian mongoose includes only the eastern part of the Neretva river valley - from its mouth in Croatia to the city of Mostar in Bosnia and Herzegovina (Barun et al. 2008). New data confirm expansion deep in south-east directions along Trebišnjica river. The limiting factor to further natural spread in the mainland of Eastern Herzegovina could be natural barriers such as mountains in the north, colder climate and deep snow cover at higher altitudes.

The small Indian mongoose is known to be one of the most invasive species in the world (Lowe et al., 2000). Its negative impact is well known throughout its naturalized range (e.g. Gorman, 1975; Cavallini 
\& Serafini, 1995; Barun et al., 2010; Barun, 2011; Watari et al., 2008). Adaptable nature of its diet, range spreading and increase in the number and density of local population provide this species with attributes which could lead to strong negative impact on local fauna, particularly reptiles, amphibians and small mammals. So far no negative impact on local fauna in Eastern Herzegovina was detected. However, researches from the neighbouring Croatia show changes in abundances of reptiles and amphibians in six islands in the Adriatic sea. More over some species of lizards, snakes and toad are absent on islands where mongoose is present (Barun et al., 2010; Barun, 2011;). Except change in abundance, the presence of small Indian mongoose can change activities of competitive species. For example, mongoose can change activity of black rat (Rattus rattus). In some Adriatic islands where both species are present, in order to avoid predation by mongoose, black rat became more nocturnal (Barun et al., 2011). Although some observations indicate decrease in numbers of population of reptiles in mainland (Bird, 2005) there are no quantitative information about negative impact of mongoose on native species in the mainland part of its European distribution, even in area with its high-density population (Ćirović et al., 2010).

Spreading of the small Indian mongoose throughout the area of Eastern Herzegovina characterize this invasive species as highly adaptive. Continued rapid extension of species' range and new distribution data in the mainland region in the Balkans (Ćirović et al., 2010) indicate there is a need for urgent establishment of the trans-border population monitoring between Croatia, Montenegro and Bosnia and Herzegovina as well as research programmes to study its impact on native species.

\section{Acknowledgments}

$\mathrm{T}$ his work was supported by the Ministry of Science and Technological Development of the Republic of Serbia (TR 31009). We wish to express our gratitude to all collaborators in the field who helped in collecting the material for this study.

\section{References}

1. Barun, A. (2011) The small Indian mongoose (Herpestes auropunctatus) on Adriatic Islands: impact, evolution, and control. PhD thesis, University of Tennessee.

2. Barun, A., Simberloff, D., Budinski, A. (2008) A ticking timebomb? The small Indian mongoose in Europe, Aliens, 26, pp. 14-16.

3. Barun, A., Simberloff, D., Budinski, A. (2010) Impact of the small Indian mongoose on native amphibians and reptiles of the Adriatic islands, Croatia, Animal Conservation, 13, pp. 549-555.

4. Barun, A., Simberloff, D., Tvrtković, N., Pascal, M. (2011) Impact of the introduced small Indian mongoose (Herpestes auropunctatus) on abundance and activity time of the introduced ship rat (Rattus rattus) and the small mammal community on Adriatic islands, Croatia, NeoBiota, 11, pp. 51-61.

5. Bird, D. (2005) Dobar dan not Buenos dias from Durovici, The Natterjack, 128, pp.12-14

6. Cavallini, P., Serafini, P. (1995) Winter diet of the small Indian mongoose Herpestes auropunctatus, on an Adriatic Island, Journal of Mammology, 76, pp. 569-574.

7. Ćirović, D., Raković M., Milenković M., Paunović M. (2010) Small Indian Mongoose Herpestes auropunctatus (Herpestidae, Carnivora): an invasive species in Montenegro, Biological Invasions, 13, pp. 393-399.

8. Ebisu, R. J., Whittow, G. C. (1976) Temperature regulation in the small Indian mongoose (Herpestes auropunctatus), Comparative Biochemistry and Physiology, A, Comparative Physiology, 54, pp. 309-313.

9. Gorman, M. L. (1975) The diete of feral Herpestes auropunctatus (Carnivora: Viverridae) in the Fijian Islands, Journal of Zoology, 175, pp. 273-278.

10. Hays, S. T., Conant, S. (2007) Biology and impacts of Pacific island invasive species. 1. A worldwide review of effects of the small Indian mongoose Herpestes javanicus (Carnivora: Herpestidae), Pacific Science, 61, pp. 3-16

11. Kryštufek, B. (1995) Herpestes auropunctatus Hodgson, 1836. In: Mitchell-Jones JA, Amori G, Bogdanowitz W, Kryštufek B, Rejinders PJH, Spitzenberger F, Stubbe M, Thissen JBM, Vohralík V, Zima J (Eds) The atlas of European mammals (pp. 354-355). T \& AD Poyser Natural History/Academic Press.

12. Kryštufek, B., Tvrtković N (1992) New information on the introduction into Europe of the small Indian mongoose, Herpestes auropunctatus, Small Carnivore conservation, 7, pp. 16.

13. Lelo, S., (2007) Mongoose, Herpestes auropunctatus Hodgson, 1836 (Mammalia: Carnivora) u Bosni i Hercegovini, Contributions to fauna of Bosnia and Herzegovina, 3, pp. 52-57.

14. Long, J. L. (2003) Introduced mammals of the world: their history, distribution and influence. CABI Publishing.

15. Lowe, S., Browne, M., Boudjelas, S., De Poorter, M. (2000) 100 of the World's worst invasive alien species: A selection from the global invasive species database. Published by The Invasive Species Specijalist Group (ISSG) a specialist group of the Species Survival Commision (SSC) of the World Conservation Union (IUCN). 
16. Nellis, D. W. (1989) Herpestes auropunctatus, Mammalian Species, 342, pp. 1-6.

17. Nellis, D. W., McManus, J. J. (1974) Thermal tolerance of the mongoose, Herpestes auropunctatus, Journal of Mammalogy, 55, pp. 645-646.

18. Pimentel, D. (1955) Biology of the Indian mongoose in Puerto Rico, Journal of Mammalogy, 36, pp. 62-68.

19. Tvrtković, N., Kryštufek, B. (1990) Small Indian mongoose Herpestes auropunctatus (Hodgson, 1836) on the Adriatic islands of Yugoslavia. Bonner Zoologische Beiträge, 41, pp. 3-8.

20. Watari. Y., Takatsuki, S., Myiashita, T. (2008) Efects of exotic moongose (Herpestes javanicus) on the native fauna of Amami-Oshima Island, southern Japan, estimated by distribution patterns along the historical gradient of mungoose invasion, Biological Invasions, 10, pp. 7-17.

Received: 28.10.2015.

Accepted: 17.11.2015.

Čirović D \&.Toholj D. (2015) ' Distribution of Small Indian Mongoose (Herpestes auropunctatus) in the Eastern Herzegovina - spreading inside Balkan mainland, Balkan Journal of Wildlife Research, 2(2), pp. 33-37. 